\title{
Screening of apple genotypes with the columnar growth habit using control markers
}

\author{
Natalia Saveleva*, Alexander Lyzhin, Andrey Yushkov, Alexander Zemisov, and Nadezhda \\ Borzykh \\ I.V. Michurin Federal Scientific Centre, Michurina str., 30, Michurinsk, 393774, Russia
}

\begin{abstract}
One of the approaches to intensify horticulture is to introduce cultivars with an unusual canopy into commercial production. Such plants can be columnar Apple trees. In modern breeding, there is a trend to create cultivars with a compact canopy. In such orchards, it is reduced to a minimum the cost for pruning, harvesting, and protection against pest and disease, which are the main expenses in apple orchards with a traditional canopy. The use of molecular markers linked to columnar growth habit allows us to identify a physiological sign at an early stage of growth: in the juvenile period. The assessment of apple cultivars and hybrids was carried out at the I. V. Michurin Federal Scientific Centre in 2015-2018. Four markers were used in the research: Mdo. chr 10.12, C18470-25831, 29f1, and jwlr to identify plants with the columnar growth habit gene (Co). The use of various DNA markers made it possible to establish that not all of them are well linked to the Co gene. In the research process, primers were identified for markers $29 \mathrm{fl}$ and jwlr, which reliably allowed us to identify plants with columnar growth habit at the juvenile stage, which will significantly reduce the breeding process.
\end{abstract}

There are about 10-15 thousand apple cultivars in the world (Malus $\times$ domestica Borkh). Only $2 \%$ from this lot are cultivars with the columnar growth habit. This breeding direction is relatively young and is only a few decennaries old. Apple is one of the most well-known and popular fruit trees in the world because of its fruit availability, great taste qualities, and useful biochemical composition. That is why producers need to get high precious cultivars with the best consumer quality of fruits. For obtaining high yields of marketability fruits, the vigor and canopy structure are of great importance. Apple trees with the columnar growth habit are well suitable for these requirements. Besides, such trees are attractive as ornamental plants. They are exciting because of the unique canopy. Thickly growing leaves with wide leaf blades, big flowers, and colored fruits closed to the trunk create a favorable impression. Their aesthetic qualities are not lost at any time of the year. Trees of this type are widely used for ornamental purposes [1-4].

The columnar growth habit arose as a bud mutation of cv. 'McIntosh' tree, which was well described in the literature. Mutant trees have no or only a small number of side shoots. Such trees have spur-type fruiting. Shoots have short internodes; wood has specific stiffness

${ }^{*}$ Corresponding author (Автор-корреспондент): saveleva_natalya_nic@mail.ru 
and strength. The growth of apple trees with columnar growth habit is controlled by heterozygous gene (Coco). Columnar apple trees, which have immunity to scab, are of particular value. It is especially crucial for Central Russia. Such trees are the most suitable for super-intensive orchard planting. They could be a basis for organic fruit production, which could provide national immunity [5-14].

The development and putting into practice molecular markers play a significant role in modern genetic programs. These markers are linked with valuable physiological traits that provide good economic results.

Many methods are applied for the identification analysis of gene Co (columnar growth habit). For example, microsatellite SSR (Simple Sequence Repeats of nucleotides), RAPD (Random Amplified Polymorphic DNA), AFLPs (Amplified Fragment Length Polymorphisms), SCAR (Sequence Characterized Amplified Region) and QTL (Quantitative Trait Locus) markers $[15,16]$. DNA-markers linked with Co gene are widely used in breeding programs. But not all of them are reliable and suitable for Co-alleles identifying [17]. Therefore, studies to identify markers, which would provide precise results, are relevant.

Our study aimed to identify reliable primers for markers providing detection of apple genotypes with columnar growth habit.

We tested markers on the next cultivars with columnar growth habit: Strela, Kaskad, Geyser, Zeleny shum, Gotika, Priokskoue, Valyuta, Teleimon, Malyukha, Vasyugan, President, Eseniya, Kumir and hybrid forms 3-19, 11-6-2, 32-26(к), 33-57, 18-2(к), 10-32, 10-7; usual apple cultivars: Boller McIntosh, Topaz, Golden Spur, Golden Delicious, Honeycrisp, Bogatyr, Antonovka zymnaya, , Swezhest, Zhigulevskoye, Antonovka krasnaya, seedlings of hybrid family Valyuta $x$ Uspenskoye.

The amplification was done in T100 thermo cycler (BIO-RAD), for genomic DNA products, the following programs were used:

sw Bai et al. (2012) for marker C18470-25831: $\mathrm{t}^{\circ} \mathrm{C}: 95$ (5 min, 35 cycles) 94 (30 s), 55 (30 s), 72(1,5 min), 72(5 min) [11];

sw Moriya et al. (2012) for marker Mdo.chr10.12: $\mathrm{t}^{\circ} \mathrm{C}$ : 94 (5 min, 35 cycles) 94 (30 s), 55 (1 min), 72 (30 s), 72 (7 min) [18];

sw Wolters et al. (2013) for marker 29f1: $\mathrm{t}^{\circ} \mathrm{C}$ : 95 (10 min, 35 cycles) 95 (30 s), 60 (1 $\mathrm{min}), 72(30 \mathrm{~s}), 72(10 \mathrm{~min})$; для маркера jwlr: $\mathrm{t}^{\circ} \mathrm{C}: 95$ (10 min, 35 cycles) 95 (30 s), 60 (1 $\mathrm{min}), 72(30 \mathrm{~s}), 72(10 \mathrm{~min})[19]$.

The amplicons were separated by electrophoresis in $2 \%$ agarose gel. The amplified fragments' length was determined using a molecular weight marker GeneRuler 100 bp DNA Ladder (ThermoFisherScientific) [20].

All primers for the indicated markers were tested on cultivars and forms with columnar and non-columnar growth habit. When evaluating the amplification products of 12 apple cultivars with a primer to the $\mathrm{C} 18470-25831$ marker, a polymorphic fragment of $169 \mathrm{bp}$ was found in 8 of them (Figure 1.) 


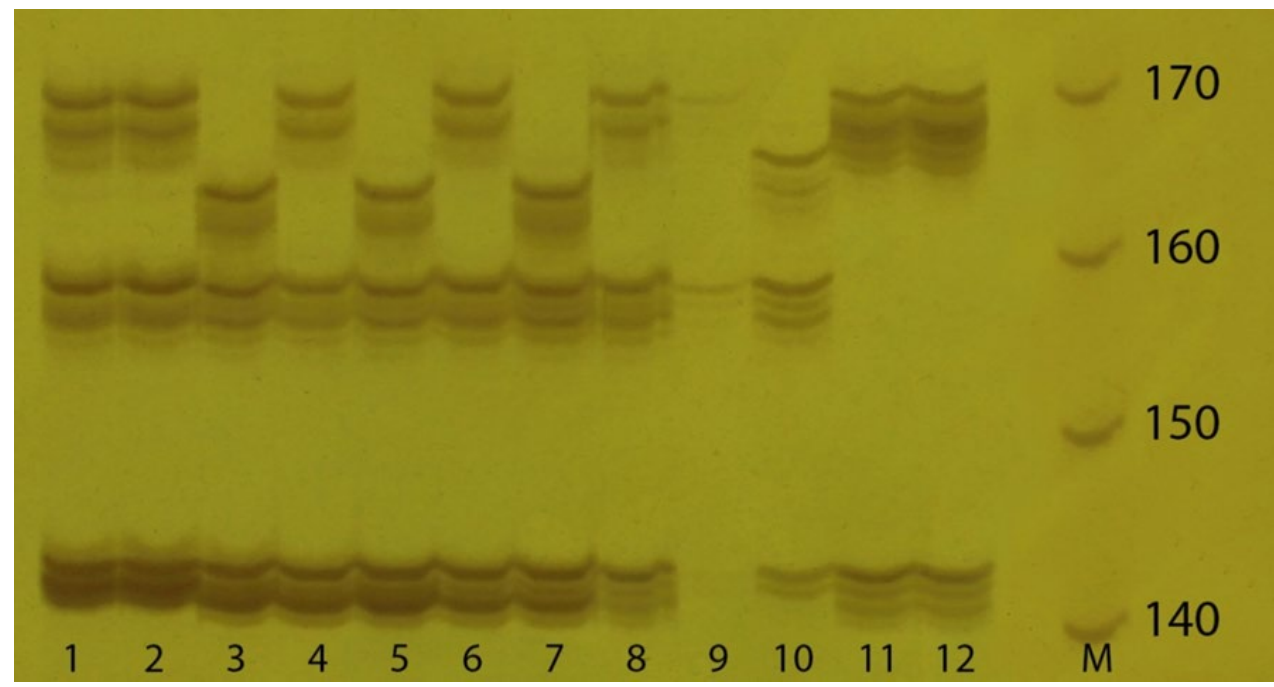

Figure 1. The electrophoretic spectrum of amplification products of the marker C18470-25831 apple genotypes

1. Valyuta, 2. Gotika, 3. Priokskoye, 4. Zeleny shum, 5. Geyzer,6. Boller McIntosh, 7. Kaskad, 8. Teleimon, 9. Topaz, 10. Strela, 11. Golden Spur, 12. Golden Delicious;

$\mathrm{M}$ - molecular weight marker

This fragment's presence indicates heterozygosity (Coco) and the attendance of the dominant allele of the $C o$ gene in the genome. The C18470-25831 marker's unreliability was established since the dominant Co-allele was found in the columnar cultivars Valyuta, Gotika, Zeleny Shum, Teleimon, and non-columnar cultivars: Boller McIntosh, Topaz, Golden Delicious, and Golden Spur. Simultaneously, it was not found in genomic DNA products of the cultivars Strela, Geyser, Priokskoye, Kaskad with columnar growth.

It causes mistrust also a primer to the marker Mdo.chr 10.12 when working with which contradicting results were obtained. An amplification fragment of $252 \mathrm{bp}$, indicating a dominant Co-allele, was found in Teleimon, Gotika, Valyuta, Zelenyi Shum with columnar growth, and in Topaz, Boller McIntosh, Golden Spur, and Golden Delicious cultivars with a normal canopy. However, it was not found in the genome of the cultivars with columnar growth Kornet, Kaskad, Priokskoe, Geyser.

Primers to markers 29f1 and jwlr confirm an insertion in the adjacent Co location in apple genotypes. In this case, a 5'CR fragment with a length of $586 \mathrm{bp}$ is fixed [19] in cultivars and hybrid forms with columnar growth, which indicates the presence of a dominant $\mathrm{Co}$-allele (Figure 2). 


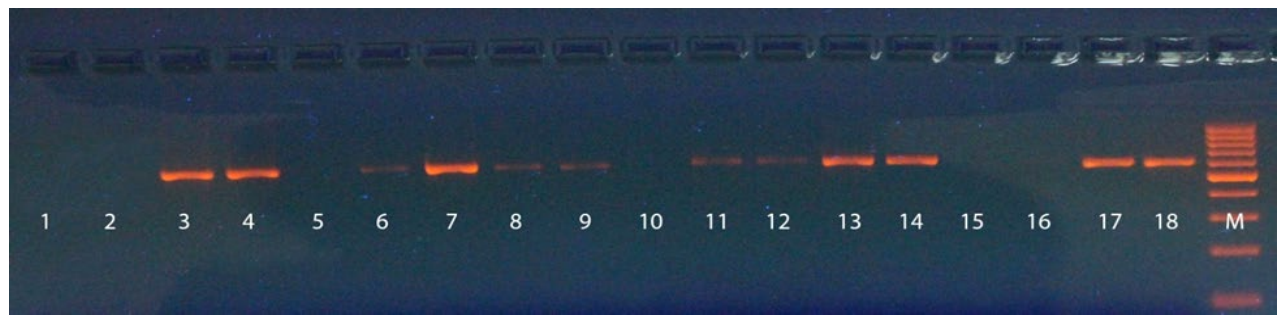

Figure 2. Molecular markers 29f1 and jw1r specific for the Co gene fragment in apple cultivars and forms

1. Honeycrisp, 2. Bogatyr, 3. 3-19, 4. Malyukha, 5. Antonovka zymnaya, 6. 11-6-2, 7. President, 8. 32-26(k), 9. Vasyugan, 10. Svezhest, 11. 33-57, 12. Eseniya, 13. Kumir, 14. 18-2(k), 15.

Zhigulevskoye, 16. Antonovka krasnaya, 17.10-32, 18. 10-7;

$\mathrm{M}$ - molecular weight marker

Cultivars Honeycrisp, Bogatyr, Antonovka Zimnyaya, Svezhest, Zhigulevskoye, Antonovka Krasnaya, which are normal apple trees, do not possess the target 5'CR fragment, which confirms the presence of an insertion in the genome. At the same time, this fragment is amplified in the columnar cultivars Malyukha, President, Vasyugan, Yesenia, Kumir and forms 3-19, 11-6-2, 32-26 (k), 33-57, 18-2 (k), 10-7. Consequently, markers 29f1 and jwlr most effectively identify the mode of apple tree growth habit. They were selected for further research.

Columnar cultivar Valyuta (Coco, Rvi6) and cv. Uspenskoe (coco, Rvi6) with the usual canopy were hybridized to evaluate the $C o$ 's gene presence in the hybrid family. Parental forms are immune to scab. Thus, the aim was set to create columnar and, at the same time, immune to scab genotypes.

Primers' use for markers 29f1 and jwlr made it possible to isolate columnar seedlings in the hybrid family Valyuta x Uspenskoe (Figure 3).

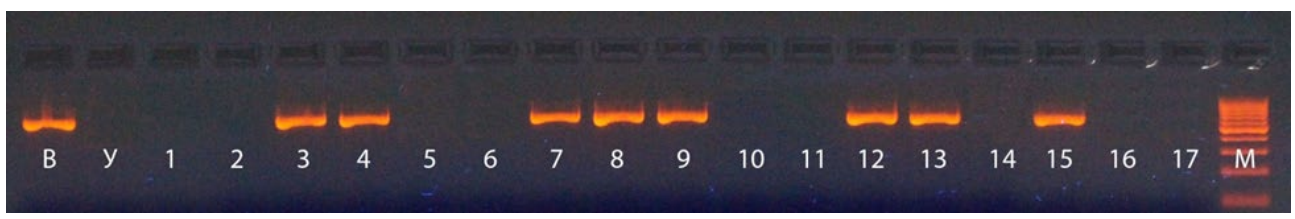

Figure 3. Moleculr 29f1 и jwlr, specific for a fragment of the Co gene, in apple hybrid offspring B: cv. 'Valyuta'; Y: cv. 'Uspenskoye'; 1-17: hybrids;

$\mathrm{M}$ - molecular weight marker

In the studied family, the segregation of columnar genotypes was about 50\%, which confirms the results obtained by Yi-Ke Tian [21]. Maternal cv. 'Valyuta' and seedlings $3,4,7,8,9,12,13,15$ carry a 586 bp 5 'CR fragment in their genome, indicating a dominant $\mathrm{Co}$ allele. In addition to the columnar gene, these genotypes are immune to scab. The Rvi6 gene in a dominant homozygous state was confirmed by analysis of genomic DNA using primers AM19-SCAR, AL07-SCAR. Thus, a unique initial material was obtained, which can be used in further breeding to create columnar varieties with monogenic scab resistance.

Apple breeding an apple tree is a difficult task that requires a lot of work. Heterozygosity for many traits, a long juvenile period, makes it difficult to isolate genotypes with desirable features. The use of molecular markers connected with genes of useful traits in modern breeding programs makes it possible to isolate the required genotypes at the earliest stages of plant development. In our research, we tested markers with columnar and non-columnar cultivars. As a result, primers for markers $29 \mathrm{fl}$ and jwlr were isolated, allowing identifying plants with columnar growth habit in the juvenile stage. Their use in the plant genetic will 
reduce the time for new cultivars breeding while saving material, labor, and financial resources.

\section{References}

1. N. I. Savel'ev, N. N. Savel'eva, Russian Journal of Genetics and Breeding, 20(4), 555562 (2016)http://doi.org/10.18699/VJ16.178

2. T. Morimoto, K. Banno, Tree Genet. Genomes, 11, 807 (2015)https://doi.org/10.1007/s11295-014-0807-0

3. C. Dan, A.F. Sestras, C. Bozdog, R.E. Sestras,Genetika, 47 (3), 993-1011(2015) https://doi.org/10.2298/GENSR1503993D

4. I.I.Suprun, A.I.Nasonov, E.V.Lobodina, E.A.Volodina, Plant biotechnology and breeding, 1(1), 25-33 (2018) http://doi.org/10.30901/2658-6266-2018-1-25-33

5. F. Dunemann, R. Gläss, S. Bartsch, M.A.S. Eldin, A.Peil, V.G.M. Bus, Tree Genet. Genomes, 8, 1095-1109 (2012) http://doi.org/10.1007/s11295-012-0489-4

6. T. Bai, Y. Zhu, F. Fernández-Fernández, J.Keulemans, S. Brown, K. Xu,Mol. Genet. Genomis, 287, 437-450 (2012) https://doi.org/10.1007/s00438-012-0689-5

7. L. Dokoupil, V. Řezníček, Acta Univ. Agric. Silvic. Mendelianae Brun, 60(8), 37-48 (2012) https://doi.org/10.11118/actaun201260080037

8. J.L. Hill jr., C.A. Hollender, Curr.Opin. Plant Biol., 47,73-80 (2019) https://doi.org/10.1016/j.pbi.2018.09.010

9. J. Blazek, Journal of Plant Studies, 2(2), 113-121 (2013) http://dx.doi.org/ 10.5539/jps.v2n2p113

10. R. Brandl, B. Brauksiepe, K. Eimert, P. Braun, D. Otto, E.R. Schmidt, Acta Hortic, 1048, 97-101 (2014) https://doi.org/10.17660/ActaHortic.2014.1048.10

11. H.B. Jacob, ActaHortic, 872, 159-164 (2010) https://doi.org/10.17660/ ActaHortic.2010.872.19

12. J.Urrestarazu, C.Denancé, E.Ravon, A.Guyader, R.Guisnel, L.Feugey, C.Poncet, M. Lateur, P.Houben, M.Ordidge, F. Fernandez-Fernandez, K.M. Evans, F.Paprstein, J.Sedlak, H.Nybom, L.Garkava-Gustavsson, C. Miranda, J. Gassmann, M.Kellerhals, I.Suprun, A.V. Pikunova, N.G. Krasova, E.Torutaeva, L.Dondini, S. Tartarini, F. Laurens, C.E.Durel, BMC Plant Biology, 16, $130 \quad$ (2016) http://doi.org/10.1186/s12870-016-0818-0

13. S. Moriya, K. Okada, T. Haji, T.Yamamoto, K. Abe, Plant Breeding, 131 (5), 641-647 (2012) https://doi.org/10.1111/j.1439-0523.2012.01985.X

14. P.J. Wolters, H.J. Schouten, R. Velasco, A. Si-Ammour, P. Baldi, New Phytol., 200(4), 993-999 (2013) https://doi.org/10.1111/nph.12580

15. P. Baldi, P.J. Wolters, M. Komjanc, R. Viola, R. Velasco, S. Salvi, Mol. Breeding, 31, 429-440 (2013) https://doi.org/10.1007/s11032-012-9800-1 